\title{
Application of Diversity Indices in the Study of Trees and Shrubs of the Nun River Forest, Nigeria
}

\author{
Felix Okponanabofa Youkparigha ${ }^{{ }^{*}}$, Dudutari Edmund Patani ${ }^{2}$ \\ ${ }^{I}$ Department of Biological Sciences, Faculty of Science, Niger Delta University, Wilberforce Island, Bayelsa \\ State, Nigeria \\ ${ }^{2}$ Department of Biological Sciences, Faculty of Science, Bayelsa Medical University, Yenagoa, Bayelsa State, \\ Nigeria
}

*Corresponding Author: Felix Okponanabofa Youkparigha, Department of Biological Sciences, Faculty of Science, Niger Delta University, Wilberforce Island, Bayelsa State, Nigeria

\begin{abstract}
Nun River forest is one of the major forests in Bayelsa state. But due to industrialization the forest is being impacted by human activities. This study evaluated the trees and shrubs of the Nun River forest reserve in Bayelsa state, Nigeria using diversity indices. The study was carried out from 2008 - 2009 in the Nun River forest using random sampling techniques. Four $50 \mathrm{~m}$ by $10 \mathrm{~m}$ transects (50m apart) were laid, two on either side of a bush path. Each of the four plots was divided into five thus, $10 \mathrm{~m}$ by $10 \mathrm{~m}$ sub-plots. All trees and shrubs greater or equal to 2 metres $(\geq 2 \mathrm{~m})$ height in each sub-plot were identified by the assistance of foresters and identification guide. The study recorded a total of 29 trees and shrubs belonging to 18 families; Euphorbiaceae (had 4 species), Rubiaceae (had 3 species), Annonaceae, Apocynaceae, Irvingiaceae, Moraceae, Myristicaceae and Palmae (had 2 species each), while Ctenolophonaceae, Guttiferae, Lamiaceae, Loganiaceae, Malvaceae, Ochnaceae, Passifloraceae, Polygalaceae, Rutaceae and Salicaceae (had 1 species each). The ecosystem showed slight alteration in species richness based on Shannon Wiener index. Slight variation exists among the diversity indices across the various plots. Comparison of the diversity using $t$-test between the various plots showed that there is significant difference $(p<0.05)$ in the interaction between Plot 3 - Plot 1, and Plot 2 - Plot 1. The Bellinger's coefficient showed no major discontinuity in the horizontal distribution in the population status of each plot. Apart from the interaction of Plot 4 - Plot 3, Jaccard index values were > 0.5 or $50 \%$ critical values, while Sorenson quantitative index showed that the similarity is> 0.5 or $50 \%$ critical values for similarity except for interaction between Plot 4 - Plot 3 and Plot 4 - Plot 2, an indication of species similarity in the various locations. Hence, the distribution of individual trees and shrubs in the Nun River forest reserve in Bayelsa state is essential in assessing the size of the conservation units.
\end{abstract}

Keywords: Diversity indices, Nun River forest reserve, Shrubs, Trees

\section{INTRODUCTION}

Plants generally are an integral part of the ecosystem, and play several roles including protection, recreation, productivity, nutrition and medicine. Most plants, including shrubs and trees, have been reported to play essential roles in the control of soil erosion, contribute in the stabilization of climate among others. But in the recent times, the global forests have been decreasing due to several human factors including agricultural activities, urbanization, industrialization, population growth, bush burning (Izah et al., 2017, 2018, Izah and Seiyaboh, 2018a,b; Izah, 2018). During long term reversible or irreversible human activities in forest, its resources including plants and animals are affected with regard to their composition, distribution and abundance. Zhigila et al. (2015) and Fries and Herman (1990) reported that on annual basis about 294.020 square kilo metres of the world's forests disappear. Close to 3 decades from this estimation, the global population has increased. As such, the diminishing rate of global forest could have far exceeded this approximation.

In taxonomy (a branch of science involved in classification of organisms in a systematic manner), plants are classified into Divisions, Classes, Orders, Families (sometimes into sub-families), Genera 
and Species. Authors have interpreted taxonomic diversity as differences among and within species (Moksia et al., 2012; Zhigila et al., 2015). In the ecosystem diversity, there are differences in bio geographic regions, landscapes and habitats (Zhigila et al., 2015). In many regions of the world, the ecosystem resources are being over exploited which has had adverse effects on the ecosystem and even in the environment at large. For instance, during the huntfor bush meat, the forest is sometimes intentionally destroyed with fire which does not only affect the targeted wildlife but also the plant resources (Izah et al., 2017). As such, ecosystem management is very important for the conservation and protection of biodiversity (Izah, 2018).

In the Niger Delta region of Nigeria, the ecosystem which plays several ecological, economic, sociocultural, scientific and recreational roles is under threat. For instance, human activities such as logging of timber resources (shrubs and trees), agriculture and developmental projects are leading factors contributing to the decline of biodiversity of the region. The establishment of the Niger Delta University in 2000 with the subsequent construction of a road through the forest linking the state capital (Yenagoa) to the University and the recent establishment of an airport in the area are examples of developmental projects that have negatively impacted on the biodiversity of the Nun river forest (Izah and Seiyaboh, 2018a).

In ecological studies, species diversity is an important conceptthat is useful in understanding the interactions between humans and their environment (Begossi, 1996). Diversity indices have been applied in the study of populations of living organisms in their environment (aquatic and terrestrial). Plants, specifically, have been widely studied using diversity indices because it allows comparison of populations in different areas, as well as determining the intensity of resources used by human populations (Begossi, 1996).

In vegetation studies, there is a linear relationship between species richness, diversity, and maturity rates and ecological factors (including altitude, aspect, and distances) of the vegetation composition (Shaheen et al., 2011; Schuster and Diekmann, 2005). In addition, ecological factors such as altitude may have a direct relationship with indigenous flora of any area. Other studies have indicated relationship between plant species richness, climatic condition, and spatial-temporal variables of a given area (Shaheen et al., 2011; Nautiyal et al., 2001, 2004; Kala and Mathur, 2002; Panthi et al., 2007). Therefore, this study is aimed at assessing the trees and shrubs of the Nun River forest using diversity indices.

\section{Materials ANd Methods}

\subsection{Study Area}

The Nun River forest which was proposed for a forest reserve under the old Rivers State. The forest is rich in biodiversity and used to be home of important animals including African buffalos (Syncerus coffa), elephant (Loxondonta africana), and Pygmy hippos (Hexaprotodon liberiensis) which have not been seen in the area for about 30 years now (Hamadina et al., 2007; Izah and Seiyaboh, 2018a). About 21 wildlife that are in the area are tagged for trade prohibition under stipulated licensing Act 11 of 1985 of the Federal Republic of Nigeria in compliance with convention on international trade of endangered species of 1973 (Hamadina et al., 2007; Izah and Seiyaboh, 2018a). The vegetation cover of the forest such as Musanga cecropoides is being affected by water flooding (Ohimain et al., 2014).

\subsection{Sampling Processes}

This study of the diversity of trees and shrubs was carried out from 2008 - 2009in the Nun River forest using random sampling techniques. Four $50 \mathrm{~m}$ by $10 \mathrm{~m}$ transects $(50 \mathrm{~m}$ apart) were laid, two on either side of a bush path. Each of the four plots was divided into five $10 \mathrm{~m}$ by $10 \mathrm{~m}$ sub-plots that were randomly labeled A-E (Figure 1). All trees and shrubs greater or equal to 1metre $(\geq 1 \mathrm{~m})$ height in each sub-plot were identified by assistance of certified foresters and identification guides by Nyananyo (2006), Adiribe and Illoh (2007). 


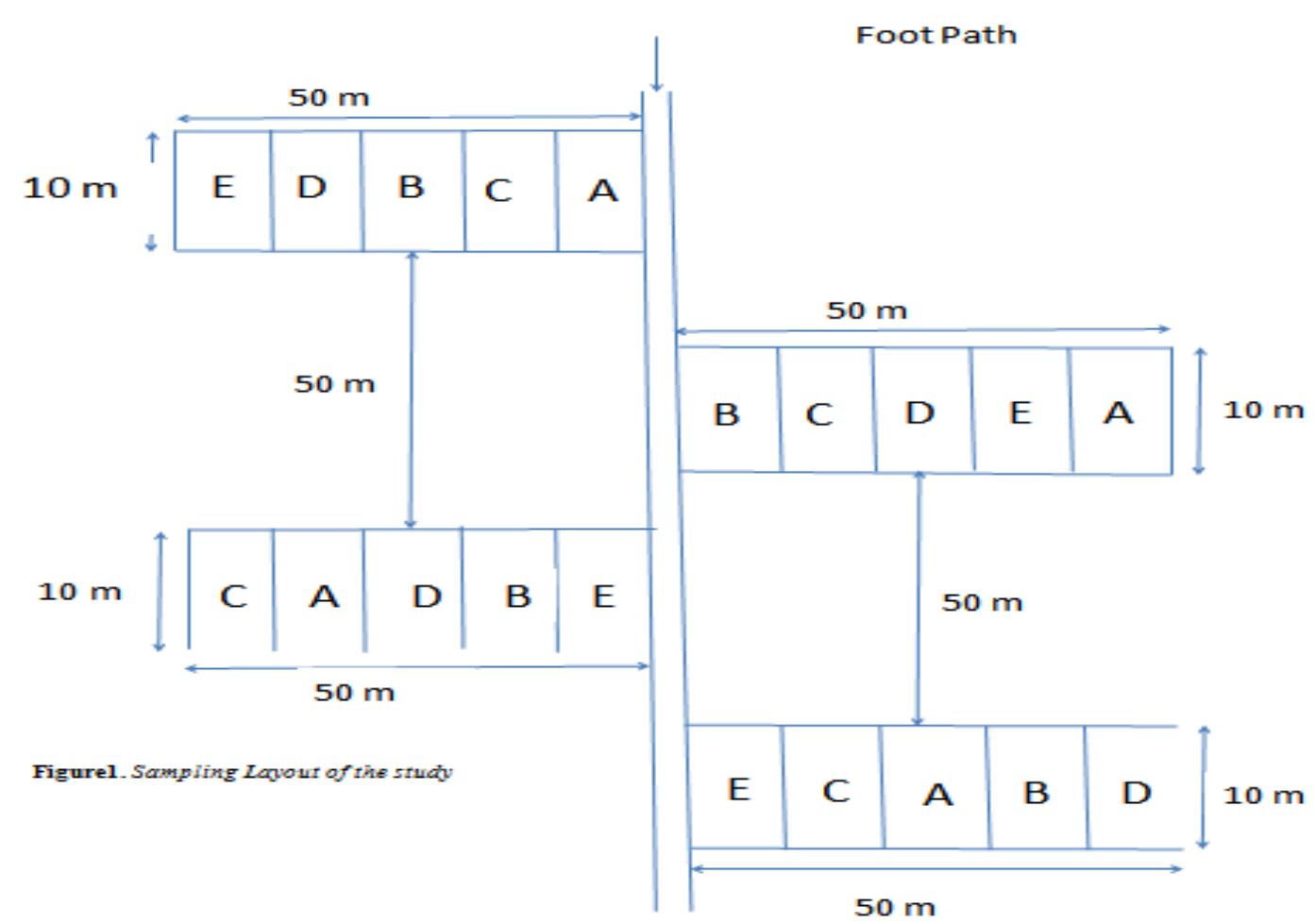

Figure1. Graphical illustration of the study plot in Nun river forest reserve in Bayelsa state, Nigeria

\subsection{Diversity Indices, Similarity and Cluster Analysis}

The diversity, species richness and diversity t-test was calculated using Paleontological statistics software package by Hammer et al. (2001). Diversity t-test was used to compare diversity of the plots. Furthermore, similarity was calculated using Sorenson index as modified by Bray and Curtis to handle quantitative data (Ogbeibu, 2014). Jaccard index and Bellinger's coefficient was also calculated based on the method previously described by Ogbeibu (2014).

Sorenson Quantitative index $==\frac{2_{\mathrm{jN}}}{(\mathrm{aN}+\mathrm{bN})}$

Where $\mathrm{aN}=$ Sum of individuals in each plot $\mathrm{A}, \mathrm{bN}=$ Sum of individuals in each plot $\mathrm{B} ; \mathrm{jN}=$ sum of the lower of the two abundance for each species in each of the plots.

Jaccard index $=\frac{\mathrm{j}}{(\mathrm{a}+\mathrm{b}-\mathrm{j})}$

Where $\mathrm{j}=$ species found at both plot being compared, $\mathrm{a}=$ number of species found in plot $\mathrm{A} ; \mathrm{b}=$ number of species found at plot $B$.

Bellinger's coefficient $=\frac{(p-q)^{2}}{p+q}$

Where $\mathrm{p}=$ number of occasions on which the species occurred in greater number in plot A than plot $\mathrm{B} ; \mathrm{q}=$ number of occasions on which the species occurred in greater number in plot $\mathrm{B}$ than plot $\mathrm{A}$

\section{RESULTS AND DISCUSSION}

In the study a total of 29 trees and shrubs belonging to different genera and 18 families were identified in Nun river forest (Table 1). The most common plant species (species that occurred in all the plots) were Cleistopholis patens (Annonaceae), Rauvolfia vomitoria (Apocynaceae), Ctenolophon englerianus (Ctenolophonaceae), Uapaca heudelotii (Euphorbiaceae), Irvingiagabonensis (Irvingiaceae), Vitex grandifolia (Lamiaceae), Anthocleista djalonensis (Loganiaceae), Musanga cecropioides (Moraceae), Coelocaryon preussi (Myristicaceae), Elaeis guineensis (Palmae), Fagara macrophylla (Rutaceae). Among the families, Euphorbiaceae had the highest number of genera (4), Rubiaceae had 3 genera, Annonaceae, Apocynaceae, Irvingiaceae, Moraceae, Myristicaceae and Palmae had 2 genera each, while the rest (Ctenolophonaceae, Guttiferae, Lamiaceae, Loganiaceae, Malvaceae, Ochnaceae, Passifloraceae, Polygalaceae, Rutaceae and Salicaceae) had 1 genera each (Figure 2). The cluster analysis of the vegetation (trees and shrubs) in Nun river forest, Bayelsa state 
is presented in Figure 3. Two major cluster were formed viz: cluster 1 (with Rauvolfia vomitoria and Musanga cecropioides), and cluster 2 has several sub clusters. The close distance cluster suggests significant relationship. The various distances are an indication of the levels of association among the various species identified in the Nun river forest. For instances, the 2 species that made up the cluster 1 were the highest occurring individuals in the study area. Mammea africana and Lophira alata have equal distances. Both species have one individual and both occurred in plot C. In addition, Spondianthus preussii, Klainedoxa gabonensis and Nauclea diderrichii also have equal distances and occurred only in plot $\mathrm{D}$ with one individual each. Therefore, the various distances are a function of the number of individuals and well as the plots they occurred.

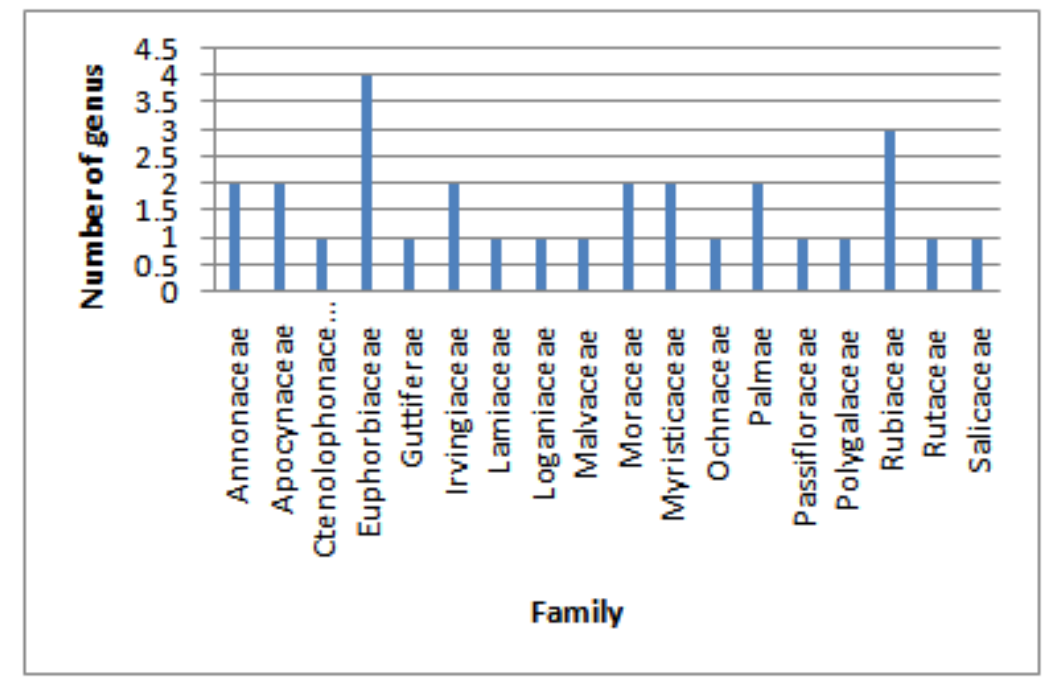

Figure2. Distribution of families of trees and shrubs in Nun River forest, Bayelsa state, Nigeria.

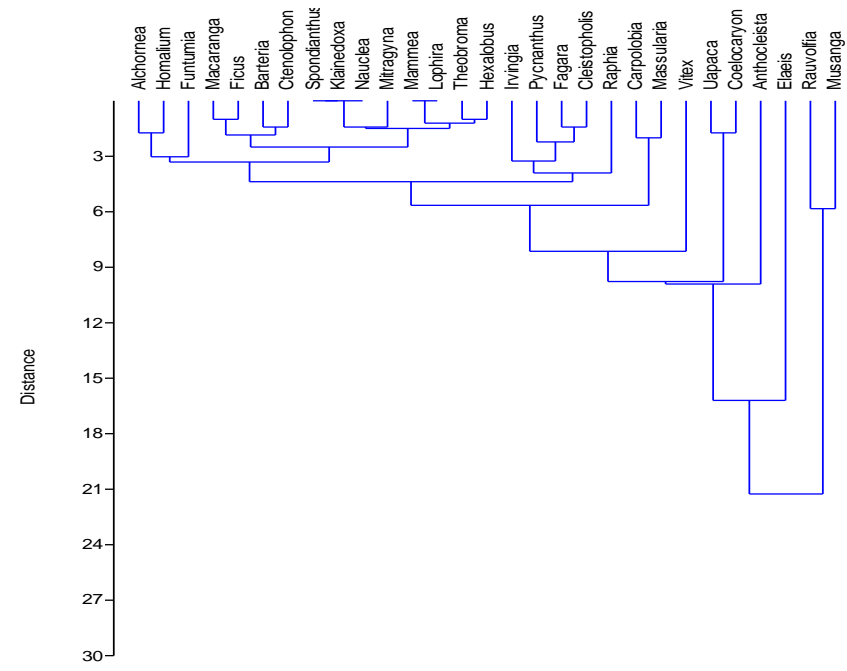

Figure3. Hierarchal cluster analysis of trees and shrubs of Nun River forest, Bayelsa state, Nigeria

Table1. Nomenclature, distribution and Composition of the trees and shrubs from Nun River Forest in Bayelsa state, Nigeria

\begin{tabular}{|c|c|c|c|c|c|c|c|c|c|c|c|c|c|c|c|c|c|c|c|c|c|c|c|c|c|c|}
\hline Plants & Family & & t 4 & & & & & & ot & & & & & & 2 & & & & & $\mathrm{Pl}$ & ot 1 & & & & & \\
\hline \begin{tabular}{|l} 
Scientific \\
names
\end{tabular} & & A & B & $\mathrm{C}$ & D & $\mathrm{E}$ & Tot & & & & & & To & $11 \mathrm{~A}$ & $B$ & $\mathrm{C}$ & $\mathrm{D}$ & $\mathrm{E}$ & Tot & $\mathrm{A}$ & B & C & $\mathrm{D} F$ & $\mathrm{E}$ & Total & $\begin{array}{l}\text { Overal } \\
\text { total }\end{array}$ \\
\hline \begin{tabular}{|l} 
Alchornea \\
cordifolia \\
(Schum. \& \\
Thonn.) \\
Müll.-Arg.
\end{tabular} & Euph & 0 & 0 & 0 & 0 & 0 & 0 & 0 & 1 & 1 & 1 & 0 & 3 & 0 & 0 & 0 & 0 & 0 & 0 & 0 & 0 & 1 & \begin{tabular}{|l|l}
0 & 1
\end{tabular} & 1 & 2 & 5 \\
\hline $\begin{array}{l}\text { Anthocleista } \\
\text { djalonensis } \\
\text { A Chev. }\end{array}$ & Logan & 3 & 0 & 0 & 0 & 3 & 6 & 0 & 0 & 1 & 0 & 0 & 1 & 0 & 3 & 0 & 2 & 4 & 9 & 1 & 0 & 1 & \begin{tabular}{|l|l}
0 & 1
\end{tabular} & 1 & 3 & 19 \\
\hline
\end{tabular}




\begin{tabular}{|c|c|c|c|c|c|c|c|c|c|c|c|c|c|c|c|c|c|c|c|c|c|c|c|c|c|c|c|}
\hline \begin{tabular}{|l} 
Barteria \\
nigritana \\
Hook.f. \\
\end{tabular} & Passifloraceae & 2 & 0 & 0 & 0 & 1 & 3 & 0 & 0 & 0 & 0 & 0 & ) & 0 & 0 & 1 & 0 & 0 & 0 & 1 & 0 & 0 & 1 & 0 & 1 & 2 & 6 \\
\hline $\begin{array}{l}\text { Carpolobia } \\
\text { lutea } \quad(\mathrm{G} . \\
\text { Don) }\end{array}$ & Polygalaceae & 0 & 0 & 0 & 0 & 0 & $\mathbf{0}$ & 0 & 0 & 0 & 0 & 0 & ) & $\mathbf{0}$ & 0 & 0 & 0 & 0 & 0 & 0 & 1 & 2 & 0 & 0 & 4 & 7 & 7 \\
\hline $\begin{array}{l}\text { Cleistopholis } \\
\text { patens } \\
\text { (Benth.) }\end{array}$ & Annonaceae & 1 & 0 & 0 & 1 & 1 & 3 & 0 & 0 & 2 & 1 & 0 & 3 & 3 & 0 & 0 & 0 & 1 & 1 & 2 & 1 & 0 & 0 & 0 & 0 & 1 & 9 \\
\hline $\begin{array}{l}\text { Coelocaryon } \\
\text { preussi } \\
\text { Warb. }\end{array}$ & Myristicaceae & 1 & 0 & 0 & 1 & 2 & 4 & 5 & 1 & 4 & 0 & 0 & 1 & 10 & 0 & 0 & 2 & 0 & 1 & 3 & 0 & 0 & 0 & 0 & 3 & 3 & 20 \\
\hline $\begin{array}{l}\text { Ctenolophon } \\
\text { englerianus }\end{array}$ & Ctenolophonaceae & 0 & 0 & 0 & 2 & 0 & 2 & 1 & 0 & 0 & 0 & 0 & 1 & 1 & 0 & 1 & 0 & 0 & 0 & 1 & 1 & 1 & 0 & 0 & 0 & 2 & 6 \\
\hline $\begin{array}{l}\text { Elaeis } \\
\text { guineensis } \\
\text { Jacq }\end{array}$ & Arecaceae & 1 & 7 & 3 & 1 & 1 & 13 & 3 & 3 & 2 & 0 & 0 & 8 & 8 & 1 & 0 & 0 & 0 & 1 & 2 & 5 & 1 & 1 & 2 & 2 & 11 & 34 \\
\hline $\begin{array}{l}\text { Fagara } \\
\text { macrophylla } \\
\text { (Oliv.) }\end{array}$ & Rutaceae & 3 & 1 & 0 & 0 & 0 & 4 & 1 & 0 & 1 & 1 & 0 & ) & 3 & 1 & 0 & 0 & 0 & 1 & 2 & 0 & 0 & 0 & 1 & 1 & 2 & 11 \\
\hline $\begin{array}{l}\text { Ficus } \\
\text { exasperata } \\
\text { Vahl }\end{array}$ & Moraceae & 0 & 0 & 0 & 0 & 1 & 1 & 0 & 0 & 0 & 0 & 0 & ) & $\mathbf{0}$ & 0 & 0 & 1 & 0 & 0 & 1 & 0 & 0 & 0 & 0 & 2 & 2 & 4 \\
\hline $\begin{array}{l}\text { Funtumia } \\
\text { africana } \\
\text { (Benth.) } \\
\text { Stapf }\end{array}$ & Apocynaceae & 0 & 0 & 0 & 0 & 0 & $\mathbf{0}$ & 0 & 0 & 0 & 1 & 0 & 1 & 1 & 2 & 0 & 0 & 0 & 1 & 3 & 0 & 0 & 1 & 0 & 1 & 2 & 6 \\
\hline $\begin{array}{l}\text { Hexalobus } \\
\text { crispiflorus } \\
\text { A. Rich. }\end{array}$ & Annonaceae & 0 & 0 & 0 & 0 & 0 & $\mathbf{0}$ & 1 & 0 & 0 & 0 & 0 & 1 & 1 & 0 & 0 & 0 & 0 & 0 & 0 & 0 & 1 & 0 & 0 & 0 & 1 & 2 \\
\hline $\begin{array}{l}\text { Homalium } \\
\text { alnifolium } \\
\text { Hutch. \& } \\
\text { Dalziel }\end{array}$ & Salicaceae & 0 & 0 & 0 & 0 & 0 & $\mathbf{0}$ & 1 & 0 & 0 & 0 & 1 & 12 & 2 & 0 & 0 & 0 & 0 & 1 & 1 & 1 & 2 & 0 & 0 & 0 & 3 & 6 \\
\hline \begin{tabular}{|l|} 
Irvingia \\
gabonensis \\
\end{tabular} & Irvingiaceae & 0 & 1 & 1 & 1 & 2 & 5 & 1 & 0 & 0 & 0 & 0 & ) & 1 & 0 & 0 & 3 & 0 & 0 & $\boldsymbol{3}$ & 0 & 0 & 0 & 1 & 0 & 1 & 10 \\
\hline $\begin{array}{l}\text { Klainedoxa } \\
\text { gabonensis } \\
\text { Pierre ex } \\
\text { Engl. } \\
\end{array}$ & Irvingiaceae & 0 & 0 & 0 & 1 & 0 & 1 & 0 & 0 & 0 & 0 & 0 & ) & 0 & 0 & 0 & 0 & 0 & 0 & 0 & 0 & 0 & 0 & 0 & 0 & 0 & 1 \\
\hline $\begin{array}{l}\text { Lophira alata } \\
\text { Banks ex } \\
\text { P.Gaertn } \\
\end{array}$ & Ochnaceae & 0 & 0 & 0 & 0 & 0 & $\mathbf{0}$ & 0 & 1 & 0 & 0 & 0 & 1 & 1 & 0 & 0 & 0 & 0 & 0 & 0 & 0 & 0 & 0 & 0 & 0 & 0 & 1 \\
\hline $\begin{array}{l}\text { Macaranga } \\
\mathrm{sp}\end{array}$ & Euphorbiaceae & 0 & 1 & 0 & 0 & 0 & 1 & 0 & 0 & 0 & 0 & 0 & 0 & 0 & 1 & 0 & 0 & 0 & 0 & 1 & 0 & 0 & 0 & 0 & 1 & 1 & 3 \\
\hline $\begin{array}{l}\text { Mammea } \\
\text { africana Sab. }\end{array}$ & Guttiferae & 0 & 0 & 0 & 0 & 0 & $\mathbf{0}$ & 1 & 0 & 0 & 0 & 0 & 1 & $\mathbf{1}$ & 0 & 0 & 0 & 0 & 0 & $\mathbf{0}$ & 0 & 0 & 0 & 0 & 0 & 0 & 1 \\
\hline $\begin{array}{l}\text { Massularia } \\
\text { acuminata (G } \\
\text { Don) } \\
\text { Bullock } \\
\end{array}$ & Rubiaceae & 0 & 0 & 0 & 0 & 0 & $\mathbf{0}$ & 0 & 0 & 0 & 0 & 0 & 0 & $\mathbf{0}$ & 0 & 0 & 0 & 0 & 0 & 0 & 1 & 2 & 0 & 0 & 2 & 5 & 5 \\
\hline $\begin{array}{l}\text { Mitragyna } \\
\text { ciliata } \\
\text { (MYTA) }\end{array}$ & Rubiaceae & 0 & 0 & 0 & 0 & 0 & $\mathbf{0}$ & 0 & 0 & 0 & 0 & 0 & ) & $\mathbf{0}$ & 1 & 0 & 0 & 0 & 0 & 1 & 0 & 0 & 0 & 0 & 0 & 0 & 1 \\
\hline $\begin{array}{l}\text { Musanga } \\
\text { cecropioides } \\
\text { R.Br. }\end{array}$ & Moraceae & 2 & 1 & 0 & 0 & 1 & 4 & 2 & 1 & 1 & 3 & 37 & 7 & 14 & 1 & 4 & 4 & 2 & 5 & 16 & 1 & 0 & 0 & 1 & 5 & 7 & 41 \\
\hline $\begin{array}{l}\text { Nauclea } \\
\text { diderrichii } \\
\text { (De Wild. } \\
\text { \&T.Durand) } \\
\text { Merr. } \\
\end{array}$ & Rubiaceae & 0 & 0 & 0 & 1 & 0 & 1 & 0 & 0 & 0 & 0 & 0 & 0 & $\mathbf{0}$ & 0 & 0 & 0 & 0 & 0 & $\mathbf{0}$ & 0 & 0 & 0 & 0 & 0 & 0 & 1 \\
\hline $\begin{array}{l}\text { Pycnanthus } \\
\text { angolensis } \\
\text { (Welw.) }\end{array}$ & Myristicaceae & 1 & 1 & 0 & 0 & 1 & 3 & 0 & 0 & 0 & ) 1 & 2 & 2 & 3 & 0 & 0 & 0 & 0 & 0 & 0 & 0 & 0 & 0 & 1 & 0 & 1 & 7 \\
\hline $\begin{array}{l}\text { Raphia vinifera } \\
\text { P.Beauv. }\end{array}$ & Palmae & 2 & 0 & 0 & 0 & 2 & 4 & 0 & 0 & 0 & 0 & 0 & 0 & 0 & 0 & 0 & 0 & 0 & 0 & 0 & 2 & 1 & 0 & 0 & 0 & 3 & 7 \\
\hline Rauvolfia & Apocynaceae & 1 & 1 & 0 & 0 & 0 & 2 & 0 & 1 & 4 & $\begin{array}{l}+2 \\
\end{array}$ & 29 & 9 & 16 & 2 & 3 & 2 & 4 & 4 & 15 & 6 & 0 & 3 & 0 & 3 & 12 & 45 \\
\hline
\end{tabular}




\begin{tabular}{|l|l|l|l|l|l|l|l|l|l|l|l|l|l|l|l|l|l|l|l|l|l|l|l|l|l|l|}
\hline $\begin{array}{l}\text { vomitoria } \\
\text { Afzel }\end{array}$ & & & & & & & & & & & & & & & & & & & & & & \\
\hline $\begin{array}{l}\text { Spondianthus Euphorbiaceae } \\
\text { preussii } \\
\text { Engl. }\end{array}$ & 1 & 0 & 0 & 0 & 0 & $\mathbf{1}$ & 0 & 0 & 0 & 0 & 0 & $\mathbf{0}$ & 0 & 0 & 0 & 0 & 0 & $\mathbf{0}$ & 0 & 0 & 0 & 0 & 0 & $\mathbf{0}$ & $\mathbf{1}$ \\
\hline $\begin{array}{l}\text { Theobroma } \\
\text { cacao L. }\end{array}$ & Malvaceae & 0 & 0 & 0 & 0 & 0 & $\mathbf{0}$ & 0 & 0 & 0 & 0 & 0 & $\mathbf{0}$ & 0 & 0 & 0 & 0 & 0 & $\mathbf{0}$ & 0 & 0 & 0 & 0 & 1 & $\mathbf{1}$ & $\mathbf{1}$ \\
\hline $\begin{array}{l}\text { Uapaca } \\
\text { heudelotii } \\
\text { Baill }\end{array}$ & Euphorbiaceae & 2 & 0 & 0 & 3 & 0 & $\mathbf{5}$ & 2 & 4 & 1 & 1 & 1 & $\mathbf{9}$ & 1 & 0 & 1 & 0 & 0 & $\mathbf{2}$ & 1 & 2 & 0 & 0 & 0 & $\mathbf{3}$ & \\
\hline $\begin{array}{l}\text { Vitex } \\
\text { grandifolia } \\
\text { Gürke }\end{array}$ & Lamiaceae & 1 & 0 & 0 & 0 & 0 & $\mathbf{1}$ & 1 & 0 & 1 & 0 & 0 & $\mathbf{2}$ & 2 & 0 & 0 & 0 & 3 & $\mathbf{5}$ & 1 & 0 & 2 & 2 & 3 & $\mathbf{8}$ & $\mathbf{1 9}$ \\
\hline
\end{tabular}

Table 2 presents the diversity indices of trees and shrub in Nun River forest, Bayelsa state, Nigeria. In Plot A, B, C and D, the number of trees and shrubs species counted were 23, 17, 18 and 19, respectively, while the total individuals in the plot were $83,68,80$ and 64 , respectively. In all, the total number of species were in the order $\mathrm{C}<\mathrm{D}<\mathrm{A}<\mathrm{D}$, while the number of individuals were $\mathrm{D}<\mathrm{B}$ $<\mathrm{C}>\mathrm{D}$.

In plots $\mathrm{A}, \mathrm{B}, \mathrm{C}$ and $\mathrm{D}$, diversity indices were $0.0765,0.1375,0.1169$ and 0.0879 , respectively (dominance), 0.9235, 0.8625, 0.8831 and 0.9121, respectively (Simpson), 2.817, 2.334, 2.423 and 2.674, respectively (Shannon Wiener index), 0.7275, 0.6068, 0.6268 and 0.7631 , respectively (Evenness), 2.525, 2.062, 2.012 and 2.375, respectively (Menhinick), 4.979, 3.792, 3.879 and 4.328, respectively (Margalef), 0.8986, 0.8237, 0.8384 and 0.9082, respectively (Equitability), and 10.53, 7.275, 7.227 and 9.133, respectively (Fisher alpha).

Based on spearman correlation (Table 3), taxa showed positive significant relationship with Simpson, Shannon Wiener index and Margalef, and negative relationship with dominance at $\mathrm{p}<0.01$. Dominance showed positive significant relationship with Simpson, Shannon Wiener index and Margalef at $\mathrm{p}<0.01$. Simpson showed positive significant relationship with Shannon Wiener index and Margalef at $\mathrm{p}<0.01$. Shannon Wiener index showed positive significant relationship with Margalef at $\mathrm{p}<0.01$. Menhinick showed positive significant relationship with Fisher alpha at $p<0.01$. Positive significant relationship between parameters is an indication that they are being influenced by each other.

During the study of trees and shrubs of Nun River forest in Bayelsa state, Nigeria, dominance was highest in Plot A (0.1375) and lowest in plot B (0.0765). The dominance value is an indication of few species in the different plots. Shannon -Wiener index ranged from 2.334 (plot B) to 2.817 (Plot A). Shannon - Wiener indexranges from $0-5$, where <1 (heavy pollution), 1 to 2 (moderate pollution) and above 3 (indicates stable conditions) (Shah and Pandit, 2013; Stub et al., 1970; Mason, 1988; Ogamba et al., 2019a, b). The Shannon -Wiener index gives useful information about the richness and evenness (Begossi, 1996). Based on the Shannon -Wiener index values, it can be deduced that the nun River forest has slight alteration in its species richness. Evenness index ranged from 0.6068 (Plot B) to 0.7631 (Plot D). The evenness index ranges from 0 (when one species is dominant) to 1 (when all species are equally abundant) (Shaheen et al., 2011). It can be deduced that the plots had quite a number of species in common. Simpson ranged from 0.8625 (Plot B) to 0.9235 (Plot A).Shaheen et al. (2011), Simpson's index provides information about the probability that two individuals selected at random will be same species. The high Simpson index suggests mature and stable community, while plots with lower values suggest effect of stress (Ogamba et al., 2019a,b) resulting from human activities in the forest.

Table2. Diversity indices in determining the distribution of the trees and shrubs from Nun River Forest in Bayelsa state, Nigeria

\begin{tabular}{|c|c|c|c|c|}
\hline Diversity indices & Plot 4 & Plot 3 & Plot 2 & Plot 1 \\
\hline Taxa_S & 19 & 18 & 17 & 23 \\
\hline Individuals & 64 & 80 & 68 & 03 \\
\hline Dominance_D & 0.0879 & 0.1169 & 0.1375 & 0.0765 \\
\hline Simpson_1-D & 0.9121 & 0.8831 & 0.8625 & 0.9235 \\
\hline Shannon Wiener index & 2.674 & 2.423 & 2.334 & 0.7275 \\
\hline Evenness_e^H/S & 0.7631 & 0.6268 & 0.6068 & 2.525 \\
\hline Menhinick & 2.375 & 2.012 & 2.062 & 4.979 \\
\hline Margalef & 4.328 & 3.879 & 3.792 & \\
\hline
\end{tabular}


Application of Diversity indices in the study of Trees and Shrubs of the Nun River Forest, Nigeria

\begin{tabular}{|c|c|c|c|c|}
\hline \multicolumn{5}{|c|}{} \\
\hline Equitability_J & 0.9082 & 0.8384 & 0.8237 & 0.8986 \\
\hline Fisher_alpha & 9.133 & 7.227 & 7.275 & 10.53 \\
\hline
\end{tabular}

Margalef index ranged from 3.792 (Plot B) to 4.979 (Plot A). Margalef index is basically used to compare species richness across the various Plots. Hence, the values suggest similarity in the species composition of the various plots. The Menhinick index ranged from 2.012 (Plot C) to 2.525 (Plot D). The Menhinick's index suggested that the species richness in the various plot are similar. The Fisher alpha ranged from 7.227 (Plot B) to 10.53 (Plot A). Again, Fisher alpha index provides useful information about the species richness (Shah and Pandit, 2013). Equitability index ranged from 0.8237 (Plot B) to 0.9082 (Plot D). The equitability index close to 1 suggest that all the plot had similar frequency, which is in the order; Plot B $<$ Plot $\mathrm{C}<$ Plot A $<$ Plot D. The equitability index provided information about the spread of the species (Ogamba et al., 2019a, b).

Table3. Spearman's rho diversity indices of trees and shrubs of Nun River Forest in Bayelsa state, Nigeria

\begin{tabular}{|c|c|c|c|c|c|c|c|c|c|c|}
\hline $\begin{array}{c}\text { Diversity } \\
\text { indices }\end{array}$ & Taxa & Individuals & Dominance & Simpson & $\begin{array}{c}\text { Shannon } \\
\text { Wiener } \\
\text { index }\end{array}$ & Evenness & Menhinick & Margalef & Equitability & Fisher_alpha \\
\hline Taxa & 1.000 & & & & & & & & & \\
\hline Individuals & .400 & 1.000 & & & & & & & & \\
\hline Dominance & $\begin{array}{c}- \\
1.000 * *\end{array}$ & -.400 & 1.000 & & & & & & & \\
\hline Simpson & $1.000 * *$ & .400 & $-1.000^{* *}$ & 1.000 & & & & & & \\
\hline $\begin{array}{c}\text { Shannon } \\
\text { Wiener } \\
\text { index }\end{array}$ & 1.000 ** & .400 & $-1.000^{* * *}$ & $1.000^{* *}$ & 1.000 & & & & & \\
\hline \begin{tabular}{|l|} 
Evenness \\
\end{tabular} & .800 & -.200 & -.800 & .800 & .800 & 1.000 & & & & \\
\hline Menhinick & .800 & .200 & -.800 & .800 & .800 & .600 & 1.000 & & & \\
\hline Margalef & $1.000^{* * *}$ & .400 & $-1.000^{* *}$ & $1.000^{* *}$ & $1.000^{* *}$ & .800 & .800 & 1.000 & & \\
\hline Equitability & .800 & -.200 & -.800 & .800 & .800 & $1.000^{* *}$ & .600 & .800 & 1.000 & \\
\hline $\begin{array}{l}\text { Fisher } \\
\text { alpha }\end{array}$ & .800 & .200 & -.800 & .800 & .800 & .600 & $1.000^{* * *}$ & .800 & .600 & 1.000 \\
\hline
\end{tabular}

**. Correlation is significant at the 0.01 level (2-tailed).

Table 4 presents t-test for comparing diversity and similarity indices between trees and shrubs of the various plots of study in a Nun River forest in Bayelsa state. Based on the t-test for comparing diversity there is significant difference $(\mathrm{p}<0.05)$ in the interaction of Plot $3-$ Plot 1 and Plot $2-$ Plot 1 , while Plot $4-$ Plot 2 showed significant difference at $\mathrm{p} \leq 0.05$. In addition, Plot $4-$ Plot 3 , Plot $4-$ Plot 1 and Plot 3 - Plot 2 showed no significant variation at $p>0.05$. The Bellinger's coefficient showed that the interaction of the plots was not significantly different since the values were less than 3.84. The Bellinger's coefficient revealed that there no major discontinuity in the horizontal distribution in the population status of each plot. Apart from the interaction of Plot 4 - Plot 3, Jaccard index values were $>0.5$ of $50 \%$ critical values. Thus the higher the joint occurrence, the higher the similarity. As such equal chance is given to each of the plant species irrespective of the individuals. This index considers only the mutual presence of species (Ogbeibu, 2014). Besides interaction of Plot 4 - Plot 3 and Plot 4 - Plot 2, Sorenson quantitative index showed that the similarity in $>0.5$ or $50 \%$ critical values for similarity. According to Shaheen et al. (2011), Sorensen's similarity index is basically used in similarities and differences in ecological studies of a plant community based on the presence or absence, as well as their associations

Table4. T-test for comparing diversity between the various plots

\begin{tabular}{|c|c|c|c|c|c|c|}
\hline & \multicolumn{2}{|c|}{ t-test for comparing diversity } & $\begin{array}{c}\text { Bellinger's } \\
\text { coefficient }\end{array}$ & $\begin{array}{c}\text { Jaccard } \\
\text { index }\end{array}$ & $\begin{array}{c}\text { Sorenson } \\
\text { quantitative index }\end{array}$ \\
\hline Interaction & t-value & df & p-value & & & \\
\hline Plot 4 - Plot 3 & 1.488 & 142.99 & 0.139 & 0.000 & 0.480 & 0.431 \\
\hline Plot 4 - Plot 2 & 1.988 & 128.60 & 0.050 & 0.818 & 0.636 & 0.485 \\
\hline Plot 4 - Plot 1 & -1.0995 & 140.53 & 0.273 & 1.923 & 0.615 & 0.558 \\
\hline Plot 3 - Plot 2 & 0.6256 & 139.41 & 0.533 & 0.818 & 0.591 & 0.635 \\
\hline Plot 3 - Plot 1 & -2.6302 & 160.32 & 0.009 & 0.077 & 0.577 & 0.589 \\
\hline Plot 2 - Plot 1 & -3.0332 & 132.54 & 0.003 & 0.333 & 0.667 & 0.636 \\
\hline
\end{tabular}




\section{CONCLUSION}

This study on the trees and shrubs diversity in the Nun River forest reserve in Bayelsa state, Nigeria, showed that the abundance and diversity of trees and shrubs differed based on the plots which could be attributed to varying levels of anthropogenic activities leading to the destruction of the forest resources such as fuel wood, timber for construction works, agricultural activities and water flooding. In the study, a total of 29 trees/shrubs were identified. Among the 18 families the species are distributed into Euphorbiaceae had the highest number of genera (4), Rubiaceae had 3 genera, Annonaceae, Apocynaceae, Irvingiaceae, Moraceae, Myristicaceae and Palmae had 2 genera each, while the rest (Ctenolophonaceae, Guttiferae, Lamiaceae, Loganiaceae, Malvaceae, Ochnaceae, Passifloraceae, Polygalaceae, Rutaceae and Salicaceae) had 1 genus each. The diversity indices provided useful information about the quality of the forest, species richness and evenness, and the level of human influence on the Nun forest reserve. The ecosystem showed slight alteration in species richness based on Shannon Wiener index. Therefore, the abundance of individual species in the forest is essential in assessing the size of the conservation units.

\section{REFERENCES}

[1] Adiribe, C. C., and Illoh, H.C. (2007). Plant Album. A Pictorial Collection of Plants in Nigeria. By S.O.S. Publications

[2] Begossi, A, (1996). Use of ecological methods in ethno-botany: diversity indices. Economic Botany 50(3):280-289.

[3] Fries, J., and Hermans, J. (1990). Natural Forest Management in Semi-Arid Africa Status and Research Needs. Unasyla - No 168 - Arid Zone Forestry File Pp. 9.

[4] Hamadina, M.K., Otobotekere, D., and Anyanwu, D.I. (2007). Impact assessment and biodiversity considerations in Nigeria: a case study of Niger Delta University campus project on wildlife in Nun River forest reserve. Management of Environmental Quality: An International Journal,18(2): 179 - 197.

[5] Hammer, Ø., Harper, D.A.T., and Ryan, P.D. (2001). PAST: Paleontological statistics software package for education and data analysis. Palaeontologia Electronica 4(1): 9pp.

[6] Izah, S. C. (2018). Ecosystem of the Niger Delta region of Nigeria: Potentials and Threats. Biodiversity International Journal, 2(4):338-345.

[7] Izah, S. C., and Seiyaboh, E. I. (2018 a). Changes in the protected areas of Bayelsa state, Nigeria. International Journal of Molecular Evolution and Biodiversity, 8(1): 1-11.

[8] Izah, S. C., and Seiyaboh, E. I. (2018b). Challenges of wildlife with therapeutic properties in Nigeria; a conservation perspective. International Journal of Avian and Wildlife Biology, 3(4): 259-264.

[9] Izah, S. C., Aigberua, A. O., and Nduka, J. O. (2018). Factors affecting the population trend of biodiversity in the Niger Delta region of Nigeria. International Journal of Avian and Wildlife Biology, 3(3): 206-214.

[10] Izah, S. C., Angaye, T. C. N., Aigberua, A. O., and Nduka, J. O. (2017). Uncontrolled bush burning in the Niger Delta region of Nigeria: potential causes and impacts on biodiversity. International Journal of Molecular Ecology and Conservation, 7(1): 1-15.

[11] Kala, C. P., and Mathur, V. (2002). Patterns of plant species distribution in the trans-Himalayan region of Ladakh, India. Journal of Vegetation Science, 13:751-754.

[12] Mason CF (1988). Biology of Fresh Water Pollution. Longman scientific and technical.

[13] Moksia, F., Louis Z., Pierre M.M., and Bernard, A.N. (2012). Woody species composition, structure and diversity of vegetation of Kalfou Forest Reserve, Cameroon. Journal of Ecology and the Natural Environment, 4(13):333-343.

[14] Nautiyal. MC., Nautiyal, B. P., and Prakash, V. (2001). Phenology and growth form distribution in an alpine pasture at Tungnath, Garhwal, Himalaya. Mountain Research and Development, 21(2):168-174.

[15] Nautiyal. M C., Nautiyal, B. P., and Prakash, V. (2001). Effect of grazing and climatic changes on alpine vegetation of Tungnath, Garhwal Himalaya, India.Environmentalist, 24:125-134.

[16] Nyananyo, B.L. (2006). Plants from the Niger Delta. Published by Onyoma Research Publication.

[17] Ogamba, E. N., Charles, E. E., and Izah, S. C. (2019a). Application of Diversity Indices in the Study Zooplankton Community of Taylor Creek in the Niger Delta, Nigeria.Sumerianz Journal of Biotechnology, 2(6): 35-41

[18] Ogamba, E. N., Charles, E. E., and Izah, S. C. (2019b). Phytoplankton Community of Taylor Creek in the Niger Delta Using Diversity Indices. Journal of Plant and Animal Ecology, 1(3): 1 - 12. 
[19] Ogbeibu, (2014). Biostatistics. A practical approach to research and data handling. $2^{\text {nd }}$ edition, Mindex publishing companioning limited, Benin City, Nigeria.

[20] Ohimain, E.I., Izah, S.C., and Otobotekere, D. (2014). Selective impacts of the 2012 water floods on the vegetation and wildlife of Wilberforce Island, Nigeria. International Journal of Environmental Monitoring Analysis, 2: $73-85$.

[21] Panthi, M. P., Chaudhary, R. P., and Vetaas, O. R. (2007). Plant species richness and composition in a trans-Himalayan inner valley of Manang district, central Nepal. Himalayan Journal of Sciences, 4(6):5764.

[22] Schuster, B., and Diekmann, M. (2005). Species richness and environmental correlates in deciduous forests of northwest Germany. Forest Ecology and Management, 206: 197-205.

[23] Shah, J. A., and Pandit, A. K. (2013). Application of diversity indices to crustacean community of Wular Lake, Kashmir Himalaya. International Journal of Biodiversity and Conservation, 5(6): 311-316

[24] Shaheen, H., Khan, S. M., Harper, D. M., Ullah, Z., and Qureshi, R. A. (2011). Species Diversity, Community Structure, and Distribution Patterns in Western Himalayan Alpine Pastures of Kashmir, Pakistan. Mountain Research and Development, 31(2):153-159. 2011.

[25] Stub, R., Appling, J. W., Hatstetter, A. M., and Hass, I. J. (1970). The effect of industrial waste of Memphis and Shelby country on primary planktonic producers. Bioscience, 20:905-912.

[26] Zhigila, D. A., Sawa, F. B. J., Abdul, S. D., Abba, H. M., and Tela, M. (2015). Diversity and Phytogeographic Investigation into Woody Plants of West Tangaza Forest Reserve, Sokoto State, Nigeria. International Journal of Plant Research, 5(4): 73-79.

Citation: Felix Okponanabofa Youkparigha \& Dudutari Edmund Patani, "Application of Diversity Indices in the Study of Trees and Shrubs of the Nun River Forest, Nigeria". International Journal of Research Studies in Biosciences (IJRSB). 7(11), pp. 1-9. DOI: http://dx.doi.org/10.20431/2349-4050.0711001

Copyright: (c) 2019 Authors this is an open-access article distributed under the terms of the Creative Commons Attribution License, which permits unrestricted use, distribution, and reproduction in any medium, provided the original author and source are credited. 